\title{
A case study on phenology and colonisation of Aedes japonicus japonicus (Theobald, 1901) (Diptera: Culicidae)
}

\author{
MARCell SÁRINGer-KenYeres ${ }^{1}$, Zoltán KenYeres ${ }^{2}$
}

\author{
${ }^{1}$ Department of Animal Sciences, Georgikon Faculty, University of Pannonia \\ H-8360 Keszthely, Deák F. u. 16., Hungary, e-mail: marcell.saringer@gmail.com \\ 2Acrida Conservational Research L.P. H-8300 Tapolca, Deák F. u. 7., Hungary, \\ e-mail: kenyeres@acridabt.hu
}

\begin{abstract}
SÁringer-Kenyeres, M., \& Kenyeres, Z.: A case study on phenology and colonisation of Aedes japonicus japonicus (Theobald, 1901).

Abstract: We investigated phenology of the invasive Aedes japonicus japonicus at Lake Balaton for two years. From July of 2017, the relative abundance of the species showed a sharp increase in the studied breeding-site - at the same time, the frequency of previously dominant species of the local larval assemblage (Ae. geniculatus and Culex pipiens pipiens) declined. In the spring of 2018, the larval assemblage was already dominated by Ae.j. japonicus, and in the rest of the year, following a minor decline in September, the relative abundance of the species continued to increase. Based on our results, Ae. j. japonicus occupied rainwater collecting barrel which had been previously considered the main habitat for $C x$. p. pipiens.
\end{abstract}

Keywords: invasive, mosquito, Hungary, artificial container, Culex pipiens pipiens

\section{Introduction}

Aedes japonicus japonicus was the third invasive mosquito species to be introduced into Europe (MEDLOCK et al. 2015). It is a multivoltine species characterised by very variable breeding sites (BECKER et al. 2003, KAUFMAN \& FonSECA 2014). In the USA, the species is often found in rock pools (SCOTT et al. 2001), which is in line with the typical characteristics of its original territory, but has also been captured in a wide variety of artificial containers (tyres, buckets, vessels, troughs) and tree holes (MrYAGI 1971, Sota et al. 1994, ScotT et al. 1999, Crans \& McNelly 1999). In Europe, regarding the occurrence of the larvae of the species, the microtechnotelms mentioned most frequently include cemetery vases (SCHAFFNER et al. 2009), outdoor ashtrays (KAMPEN \& WERNER 2014) and similar artificial containers.

The species became known in Hungary in 2012 in a sub-area neighbouring Slovenia (Felsőszölnök: SEIDEL et al. 2016). In 2017, robust populations of Ae. j. japonicus were found at Lake Balaton (Balatongyörök and Badacsonytördemic) in plastic barrels for rainwater collection (SÁRINGER-KENYERES \& KENYERES 2018). 
After the detection of the species we investigated its phenology in one of the abovementioned localities (Balatongyörök). According to our hypothesis, Ae. j. japonicus occupies the most typical breeding sites of Culex pipiens pipiens.

\section{Material and methods}

We collected mosquito larvae twice a month from July to November in 2017 and from April to November in 2018, at Balatongyörök (Bece Hill) (coordinate: N46 ${ }^{\circ} 46^{\prime} 53.27^{\prime \prime}$ E17²1'39.92"). The examined artificial container was in a spatial position from the breeding of Ae.j. japonicus (in a green-belt area bordered with small broad-leaved forest patches). The mosquito larvae were collected using a densely woven larvae-collecting net. The sampling was always carried out for the same duration and with covering the same size of water bodies. The size of the breeding location tested (diameter: $80 \mathrm{~cm}$, water depth: 20-40 cm) and its character (continuous rainwater supply, oscillating water level) ensured that the sampling influenced the size of the populations of the species as little as possible. The specimens collected during the samplings were transported to the laboratory and identified to species level. By taking the averaged data of the two collections per month, and using the total numbers of larvae in the samples, we determined the relative abundance of Ae.j. japonicus monthly.

To identify native mosquitoes, the determination keys of BECKER et al. (2003), TóTH (2007) and KenYeres \& Tóth (2008) were used, while we turned to TANAKA et al. (1979) for the identification of Ae. j. japonicus. The nomenclature follows SÁRINGERKENYERES et al. (2018).

\section{Results}

We collected 938 individuals of 11 mosquito species. Based on the pooled data, the local larval assemblage was dominated by Ae.j. japonicus, Ae. geniculatus and Cx. $p$. pipiens (Table 1).

At the commencement of the study (July 2017), Ae. j. japonicus was present in the local larval assemblage as a subordinated species. Until November 2017, the relative frequency of the species showed a sharp increase - at the same time, the frequency of Ae. geniculatus declined drastically and Cx. p. pipiens showed a decline with a fluctuating relative abundance (Fig. 1). In the spring of 2018, the larval assemblage was already dominated by Ae.j.japonicus, and in the rest of the year, following a minor decline in September, the relative abundance of the species continued to increase. The other two species (Ae. geniculatus, Cx. p. pipiens) caught in high numbers in total, except in May, were present at the breeding site only as subordinate species (Fig. 1.). 
Table 1: Species composition and monthly average abundances of larvae samples collected during study on phenology of Aedes $j$. japonicus (locality: Balatongyörök, Bece hill at Lake

Balaton, Hungary; studied breeding site: rainfall collector from concrete)

\begin{tabular}{|c|c|c|c|c|c|c|c|c|c|c|c|c|c|c|}
\hline \multirow[b]{2}{*}{ Taxon } & \multicolumn{5}{|c|}{2017} & \multicolumn{8}{|c|}{2018} & \multirow[b]{2}{*}{$\Sigma$} \\
\hline & VII & VIII & IX & $\mathbf{X}$ & XI & IV & $\mathbf{V}$ & VI & VII & VIII & IX & $\mathbf{X}$ & XI & \\
\hline Aedes j. japonicus & 16 & 37 & 12 & 36 & 7 & 43 & 37 & 53 & 49 & 55 & 148 & 9 & 7 & 509 \\
\hline Aedes geniculatus & 102 & 12 & 6 & 2 & 2 & 18 & 36 & & & 1 & 1 & 1 & & 181 \\
\hline Culex p.pipiens & 27 & 73 & 42 & 12 & 2 & 4 & 8 & 5 & 4 & & 19 & 1 & & 197 \\
\hline Culex torrentium & 5 & 1 & 10 & & & & 1 & 6 & 2 & & & & & 25 \\
\hline Culex hortensis & 1 & & 6 & & & & & & & & & 5 & & 12 \\
\hline Anopheles maculipennis & 5 & & & & & & & & & & & & & 5 \\
\hline Culex martinii & 3 & & & & & & & & & & & & & 3 \\
\hline Anopheles plumbeus & 2 & 1 & & & & & & & & & & & & 3 \\
\hline Aedes vexans & 1 & & & & & & & & & & & & & 1 \\
\hline Aedes leucomelas & & & & & & 1 & & & & & & & & 1 \\
\hline Culex territans & & & & & & & & & & & 1 & & & 1 \\
\hline$\Sigma$ & 162 & 124 & 76 & 50 & 11 & 66 & 82 & 64 & 55 & 56 & 169 & 16 & 7 & \\
\hline
\end{tabular}

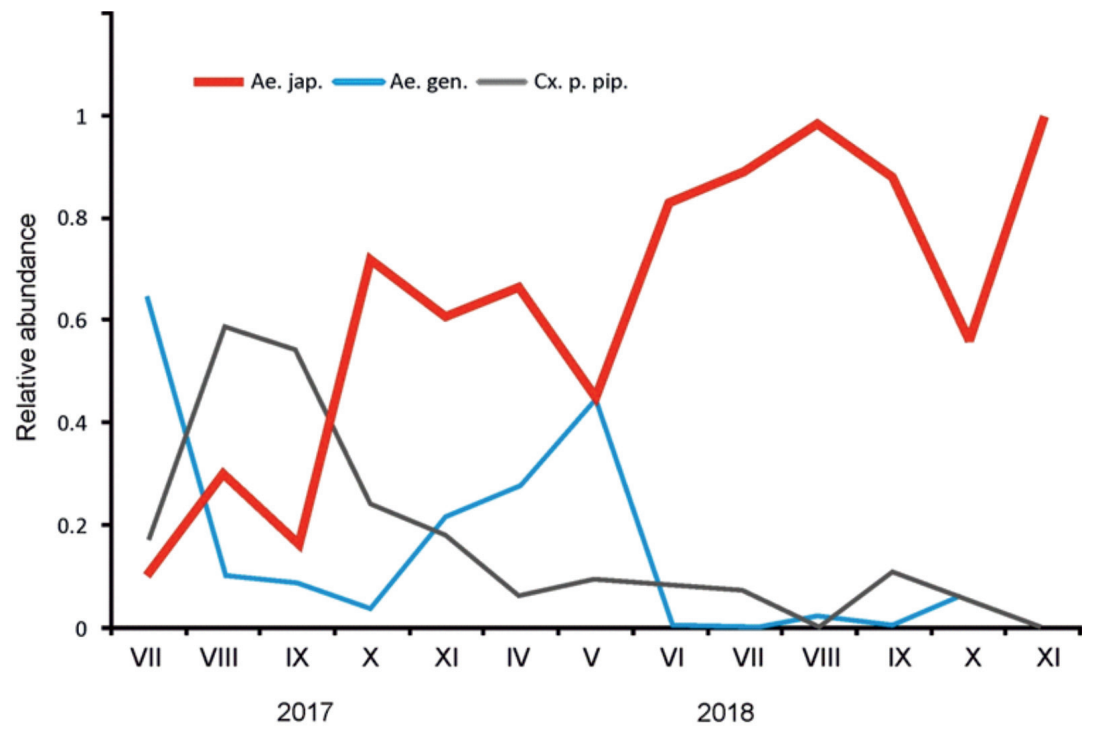

Figure 1: Relative abundances of species being dominant in mosquito assemblage occurring in breeding site studied by phenology of Aedes j. japonicus (locality: Balatongyörök, Bece hill at Lake Balaton, Hungary; studied breeding site: rainfall collector from concrete)(Ae. jap.: Aedes j. japonicus; Ae. gen.: Aedes geniculatus; Cx. p. pip.: Culex pipiens pipiens) 


\section{Discussion}

Aedes $j$. japonicus occupied the studied rainwater collecting barrel which had been previously considered the main habitat of Culex $p$. pipiens. Our phenological data confirmed the results of DAMIENS et al (2014), whereby at the breeding sites characterized by the high density of $A e . j$. japonicus, a considerable decrease in the density of $C x . p$. pipens and Ae. geniculatus can also be observed. Ae.j.japonicus has competitive advantages not only compared to native species in its invasion areas (breeding in artificial containers, laying eggs on dry surfaces, rapid development, broad food orientation), the tolerance of its larvae to the circumstances of sites and temperature is much higher than that of Ae. albopictus (SCHAFFNER et al. 2003); Ae.j. japonicus can capture the larvae habitats from Ae. albopictus, too (ARMISTEAD et al. 2012). Based on our field experiences, the strategy of Ae. koreicus, as a sibling species of Ae.j.japonicus and having a significantly more restricted local area in Hungary (KURUCZ et al. 2016), seems similar to Ae.j. japonicus. This latter fact justifies the regular and intense larvae surveillance in the artificial containers found in the anthropogenic zones with gardens bordered by forests in Hungary and other Central European countries.

\section{Acknowledgements}

The publication was supported by the EFOP-3.6.3-VEKOP-16-2017-00008 project (co-financed by the European Union and the European Social Fund).

\section{References}

Armistead, J.S., Nishimura, N., Arias, J.R. \& Lounibos, L.P. 2012: Community ecology of container mosquitoes (Diptera: Culicidae) in Virginia following invasion by Aedes japonicus. - Journal of Medical Entomology 6: 1318-1327.

Becker, N., Petric, D., Zgomba, M., Boase, C., Dahl, C., Lane, J. \& Kaiser, A. 2003: Mosquitoes and their control. Kluwer Academic/Plenum Publishers, New York, Boston, Dordrecht, London, Moscow, pp. 39-40.

Crans, W.J. \& McNelly, J.R. 1999: An update on the distribution of Aedes japonicus in the Northeast. Vector Ecology Newsletter 30(6): 14-15.

Damiens, D., Ayrinhac, A., Van Bortel, W., Versteirt, V., Dekoninck, W. \& Hance, T. 2014: Invasive process and repeated cross-sectional surveys of the mosquito Aedes japonicus japonicus establishment in Belgium. - PLoS ONE 9(4): e89358. https://doi.org/10.1371/journal.pone.0089358

KAmpen, H. \& Werner, D. 2014: Out of the bush: the Asian bush mosquito Aedes japonicus japonicus (Theobald, 1901) (Diptera, Culicidae) becomes invasive. - Parasites \& Vectors 7: 59. https://doi. org/10.1186/1756-3305-7-59

Kaufman, M.G. \& FonseCA, D.M. 2014: Invasion Biology of Aedes japonicus japonicus (Diptera: Culicidae). - Annual Review of Entomology 59: 31-49. https://doi.org/10.1146/annurev-ento-011613-162012

KenYeres Z. \& Tóth S. 2008: Csípőszúnyog-határozó II. (Imágók). [Identification keys to Mosquitoes II. (Adults).] - Pannónia Füzetek 2: 1-96. [In Hungarian]

Kurucz, K., Kiss, V., Zana, B., Schmieder, V., Kepner, A., JaKab, F. \& Kemenesi, G. 2016: Emergence of Aedes koreicus (Diptera: Culicidae) in an urban area, Hungary, 2016. - Parasitology Research 115: 4687-4689. https://doi.org/10.1007/s00436-016-5229-5 
Medlock, J.M., Hansford, K.M., Versteirt, V., Cull, B., Kampe, H., Fontenille, D., Hendrickx, G., Zeller, H., Van Bortel, W. \& Schaffner, F. 2015: An entomological review of invasive mosquitoes in Europe. - Bulletin of entomological research 105: 637-663. https://doi.org/10.1017/ S0007485315000103

Mryagi, I. 1971: Notes on the Aedes (Finlaya) chrysolineatus subgroup in Japan and Korea (Diptera: Culicidae). - Journal of Tropical Medicine 13: 141-151.

SÁRINGER-KENYERES M. \& KeNYERES Z. 2018: Invazív csípőszúnyog fajok(Diptera: Culicidae) Magyarországon. [Invasive mosquito species (Diptera: Culicidae) in Hungary.] - Conference: XXIV. Ifjúsági Tudományos Fórum, Pannon Egyetem Georgikon Kar, Keszthely, 24 May 2018

SÁringer-Kenyeres, M., Tóth, S. \& Kenyeres, Z. 2018: Updated checklist of the mosquitoes (Diptera: Culicidae) of Hungary. - Journal of the European Mosquito Control Association 36: 14-16.

Schaffner, F., Chouin, S. \& Guilloteau, J. 2003: First record of Ochlerotatus (Finlaya) japonicus japonicus (Theobald, 1901) in metropolitan France. - Journal of the American Mosquito Control Association 19: $1-5$.

Schaffner, F., Kaufmann, C., Hegglin, D. \& Mathis, A. 2009: The invasive mosquito Aedes japonicus in Central Europe. - Medical and Veterinary Entomology 23: 448-451. https://doi. org/10.1111/j.1365-2915.2009.00825.x

Scott, J.J., McNelly, J.R. \& CRAns, W.J. 1999: Aedes japonicus overwinters in New Jersey. - Vector Ecology Newsletter 30: 6-7.

SCOTt, J.J., Frank, L.C. \& CrAns, W.J. 2001: Ochlerotatus japonicus collected from natural rockpools in New Jersey. - Journal of the American Mosquito Control Association 17: 91-92.

Seidel, B., Nowotny, N., Bakonyi, T., Allerberger, F. \& Schaffner, F. 2016: Spread of Aedes japonicus japonicus (Theobald, 1901) in Austria, 2011-2015, and first records of the subspecies for Hungary, 2012, and the principality of Liechtenstein, 2015. - Parasites \& Vectors 9: 356-362. https://doi.org/10.1186/ s13071-016-1645-8

Sota, T., Mogi, M. \& Hayamizu, E. 1994: Habitat stability and the larval mosquito community in treeholes and other containers on a temperate island. - Researches on Population Ecology 36: 93-104. https://doi. ORG/10.1007/BF02515090

Tanaka, K., Mizusawa, K. \& Saugstad, E.S. 1979: A revision of the adult and larval mosquitoes of Japan (including the Ryukyu Archipelago and the Ogasawara Islands) and Korea (Diptera: Culicidae). Contributions of the American Entomological Institute 16: 1-987.

Tóтн S. 2007: Csípőszúnyog-határozó I. (Lárvák). [Identification keys to Mosquitoes I. (Larvae).] - Pannónia Füzetek 1: 1-96. 
